\title{
PENGARUH NON PERFORMING FINANCING (NPF), FINANCING TO DEPOSIT RATIO (FDR) dan CAPITAL ADQUACY RATIO (CAR) TERHADAP RETURN ON EQUITY (ROE) BANK SYARIAH (Studi Kasus pada Bank Umum Syariah di Indonesia Tahun 2015-2019)
}

\author{
Sri Mulyani1) \\ 1)Institut Agama Islam Sunan Kalijogo Malang \\ 1)
}

\begin{abstract}
Abstrak. Tujuan penelitian adalah untuk mengetahui pengaruh Non Performing Financing (NPF), Financing to Deposit Ratio (FDR) dan Capital Adquacy Ratio (CAR) terhadap Retun On Equity (ROE) bank syariah baik secara parsial maupun secara simultan. Penelitian ini merupakan penelitian kuantitatif dengan pendekatan explanatory. Populasi dalam penelitian ini adalah seluruh Bank Umum Syariah di Indonesia. Sampel dalam penelitian ini dilakukan secara purposive sampling yang menghasilkan sampel sebanyak 4 Bank Umum Syariah. Sumber data dalam penelitian ini adalah data sekunder yang diambil dari laporan publikasi ilmiah dari website bank umum syariah, website Bank Indonesia dan website Otoritas Jasa Keuangan (OJK). Pengambilan data diambil secara time series selama lima tahun secara triwulan sehingga jumlah pengamatan adalah sebanyak 80 pengamatan dan 320 data.

Analisis data dilakukan dengan melakukan uji regresi linier berganda dengan SPP 25 yang meliputi uji statistik deskriptif, uji asumsi klasik, uji t dan uji F. Penelitian ini menghasilkan bahwa pengaruh NPF terhadap ROE didapatkan nilai t sebesar -5.11 dengan signikansi 0.000 sehingga $\mathrm{T}_{\text {hitung }}>\mathrm{T}_{\text {tabel }}(-5.11>1.99)$ dan signifikansi $0.000<$ 0.05. Sehingga NPF berpengaruh negatif dan signikan. Pengaruh FDR terhadap ROE didapatkan nilai $t$ sebesar -2.249 dengan signikansi 0.000 sehingga $\mathrm{T}_{\text {hitung }}>\mathrm{T}_{\text {tabel }}(-$ $2.249>1.99$ ) dan signifikansi $0.27>0.05$ sehingga FDR berpengaruh negatif dan tidak signifikan terhadap ROE. Pengaruh CAR terhadap ROE didapatkan nilai t sebesar 0.959 dengan signikansi 0.352 sehingga $\mathrm{T}_{\text {hitung }}<\mathrm{T}_{\text {tabel }}(0.959>1.99)$ dan signifikansi $0.352>$ 0.05 sehingga CAR berpengaruh positif dan tidak signifikan terhadap ROE. Sedangkan pada uji simultan didapatkan nilai $F$ sebesar 9.369 dengan signikansi 0.001 sehingga $\mathrm{F}_{\text {hitung }}>\mathrm{T}_{\text {tabel }}(9.359>2.72)$ dan signifikansi $0.001<0.05$ sehingga secara simultan NPF, FDR dan CAR berpengaruh positif dan signifikan terhadap ROE.
\end{abstract}

Kata Kunci: NPF, FDR, CAR, ROE, Bank Syariah

Abstract. This study aims to determine the effect of Non Performing Financing (NPF), Financing to Deposit Ratio (FDR) and Capital Adquacy Ratio (CAR) on the Return On Equity (ROE) of Islamic banks either partially or simultaneously. This research is a quantitative research with an explanatory approach. The population in this study were all Islamic Commercial Banks in Indonesia. The sample in this study was conducted by purposive sampling which resulted in a sample of 4 Islamic Commercial Banks. The source of data in this study is secondary data taken from scientific publication reports from the website of Islamic commercial banks, the website of Bank Indonesia and the website of the Financial Services Authority (OJK). Data collection was taken in a time series for five years on a quarterly basis so that the number of observations was 80 observations and 320 data. Data analysis was carried out by performing multiple linear regression tests with SPP 25 which included descriptive statistical tests, classical assumption tests, $t$ tests and $F$

${ }^{1}$ Penulis adalah Dosen Tetap Institut Agama Islam Sunan Kalijogo Malang. 
tests. This study resulted that the effect of NPF on ROE obtained a $t$ value of -5.11 with a significance of 0.000 so that Tcount $>$ T table $(-5.11>1.99)$ and a significance of $0.000<$ 0.05. So that the NPF has a negative and significant effect. The effect of FDR on ROE obtained $t$ value of -2.249 with a significance of 0.000 so that Tcount $>$ Ttable ($2.249>1.99)$ and a significance of $0.27>0.05$ so that FDR has a negative and insignificant effect on ROE. The effect of CAR on ROE obtained a t value of 0.959 with a significance of 0.352 so that Tcount $<T$ table $(0.959>1.99)$ and a significance of $0.352>0.05$ so that CAR has a positive and insignificant effect on ROE. Meanwhile, in the simultaneous test, the $F$ value was 9.369 with a significance of 0.001 so that Fcount $>T$ table $(9.359>2.72)$ and a significance of $0.001<0.05$ so that simultaneously NPF, FDR and CAR had a positive and significant effect on ROE.

Keywords: NPF, FDR, CAR, ROE, Islamic Bank

\section{PENDAHULUAN}

Ekonomi syariah di Indonesia pada saat ini telah berkembang cukup pesat. Salah satunya terlihat dari eksistensi perkembangan perbankan syariah yang ada pada saat ini. Perbankan syariah mempunyai peran yang penting dalam pertumbuhan perekonomian negara secara umum karena bank syariah berfungsi sebagai lembaga intermediasi dari surplus unit kepada defisit unit yang operasionalnya sesuai dengan prinsip-prinsip syariah Islam. Menurut Muhammad Abduh dan Mohd Azmi Omar bahwa dalam waktu jangka panjang, perbankan syariah dan keuangan Islam memiliki peran penting dan positif terhadap pertumbuhan ekonomi². Pembiayaan yang dilakukan oleh perbankan syariah di Indonesia pada dasarnya berperan untuk merangsang pertumbuhan ekonomi. Hal ini karena konsep bagi hasil yang diusung perbankan syariah lebih mendorong perkembangan sektor riil. Selain itu, perbankan syariah mendorong pembagian pendapatan secara lebih yang dalam jangka panjang bisa menciptakan keadilan sosial. Demikian juga dengan skema pembagian laba-rugi akan meningkatkan efisiensi alokasi modal dan meningkatkan produktivitas.

Untuk bisa menjalankan fungsinya dengan baik, bank syariah harus mampu menjaga tingkat kesehatan keuangannya. Beberapa permasalahan utama yang harus dihadapi oleh perbankan syariah terkait dengan kesehatan keuangannya antara lain adalah terkait likuiditas, Non Performance Financing (NPF), Financing to Deposit Ratio (FDR) dan rasio kecukupan modal (CAR) serta tingkat profitabilitas bank syariah. Penelitian sebelumnya yang dilakukan oleh Almunawwaroh menunjukkan bahwa Capital Adquacy Ratio (CAR) dan Non

2 Safaah Restuning Hayati, "Peran Perbankan Syariah Terhadap Pertumbuhan Ekonomi Indonesia," Indo-Islamika 24, no. 1 (2014): 47-55. 
Performance Financing (NPF) berpengaruh negatif signifikan pada Retun on Asset (ROA)3. Sedangkan penelitian yang dilakukan Munir membuktikan bahwa secara simultan NPF, FDR dan CAR berpengaruh signifikan terhadap ROA4 . Sedangkan secara parsial NPF berpengaruh positif signifikan terhadap ROA, namun CAR dan FDR tidak berpengaruh terhadap ROA5. Sementara itu, penelitian yang dilakukan oleh Idrus menghasilkan bahwa CAR dan FDR berpengaruh terhadap Return on Equity (ROE) pada bank syariah yang ada di Indonesia. Penelitian ini bertujuan untuk mengetahui apakah secara parsial maupun simultan Non Performance Financing (NPF), Financing to Deposit Ratio (FDR) dan Capital Adquacy Ratio (CAR) berpengaruh terhadap Return On Equity (ROE) pada Bank Umum Syariah di Indonesia. Alasan penulis untuk melakukan penelitian ini adalah pada penelitian sebelumnya sebagian besar profitabilitas bank syariah diproksikan dengan Return on Asset (ROA). Padahal untuk mengetahui tingkat profitabilitas bank syariah selain diukur menggunakan ROA juga bisa dilakukan dengan menggunakan Return On Equity (ROE). Selain itu, beberapa hasil penelitian terdahulu masih menghasilkan hasil penelitian yang berbeda-beda sehingga penulis tertarik untuk meneliti pengaruh NPF, FDR dan CAR terhadap ROE bank syariah dengan menggunakan data yang terbaru. Oleh karena rumusan masalah dalam penelitian ini adalah :

1. Apakah Non Performance Financing (NPF) berpengaruh secara parsial terhadap Return On Equity (ROE) Bank Umum Syariah di Indonesia?

2. Apakah Financing to Deposit Ratio (FDR) berpengaruh secara parsial terhadap Return On Equity (ROE) Bank Umum Syariah di Indonesia?

3. Apakah Capital Adquacy Ratio (CAR) berpengaruh secara parsial terhadap Return On Equity (ROE) Bank Umum Syariah di Indonesia?

4. Apakah CAR, FDR dan CAR secara simultan berpengaruh terhadap Return On Equity (ROE) Bank Umum Syariah di Indonesia?

${ }^{3}$ Medina Almunawwaroh, "Pengaruh CAR, NPF Dan FDR Terhadap Profitabilitas Bank Syariah Di Indonesia," Amwaluna: Jurnal Ekonomi Dan Keuangan Syariah 2, no. 1 (2018): 1-18, https://doi.org/https://doi.org/10.29313/amwaluna.v2i1.3156.

4 Misbahul Munir, "Analisis Pengaruh CAR, NPF, FDR Dan Inflasi Terhadap Profitabilitas Perbankan Syariah Di Indonesia," Ihtifaz: Journal of Islamics, Finance, and Banking 1, no. 2 (2018).

${ }^{5}$ Ibid 


\section{METODE PENELITIAN}

\section{Jenis dan Pendekatan Penelitian}

Jenis penelitian ini adalah penelitian kuantitatif dengan pendekatan explanatory yaitu penelitian yang menggambarkan dan menjelaskan hubungan antara variabel independen dengan variabel dependen.

\section{Variabel Penelitian}

Penelitian ini terdiri dari tiga variabel bebas (independen) dan satu variabel terikat (dependen). Variabel bebas dalam penelitian ini adalah Non Performing Financing (NPF), Financing to Deposit Ratio (FDR) dan Capital Adquacy Ratio (CAR). Sedangkan variabel terikat dalam penelitian ini adalah Return On Equity (ROE).

\section{Populasi dan Sampel Penelitian}

Populasi dalam penelitian ini adalah seluruh Bank Umum Syariah di Indonesia. Teknik pengambilan sampel dilakukan secara purposive sampling dengan maksud bahwa bank syariah yang menjadi sampel pada penelitian ini adalah yang mampu memberikan informasi untuk medapatkan tujuan dari penelitian ini. Adapun sampel dalam penelitian ini adalah :

Tabel 2.1

Sampel Penelitian

\begin{tabular}{|c|l|}
\hline No & Nama Bank \\
\hline 1 & Bank Muamalat Indonesia \\
\hline 2 & Bank Syariah Mandiri \\
\hline 3 & BRI Syariah \\
\hline 4 & BNI Syariah \\
\hline
\end{tabular}

\section{Sumber Data Penelitian}

Data yang digunakan dalam penelitian ini adalah data sekunder yang diambil dari data publikasi pada website masing-masing Bank Umum Syariah, website Bank Indonesia (www.bi.go.id), dan Website Otoritas Jasa Keuangan (www.ojk.go.id). Data diambil secara time series pada periode 2015-2019. Data diambil secara triwulan dari empat Bank Umum Syariah yang dijadikan sebagai sampel penelitian. Sehingga jumlah pengamatan yang dilakukan dalam penelitian ini adalah sebanyak 80 pengamatan (4 BUS x 5 tahun x 4 triwulan $=80$ pengamatan). Sedangkan jumlah data yang terkumpul adalah sebanyak 320 data yang diperoleh dari 80 pengamatan dikalikan dengan 4 variabel. Data sekunder juga diambil dari literatur buku-buku dan jurnal ilmiah yang terkait dengan penelitian ini. Data yang terkumpul kemudian diolah dengan menggunakan teknik analisis data regresi linier berganda dengan alat analisis data SPSS 25. Teknik analisis data yang digunakan dalam penelitian ini adalah menggunakan uji asumsi klasik yaitu uji normalitas, uji linieritas, uji 
heteroskedastisitas, uji multikolinieritas dan uji autokorelasi. Setelah dilakukan uji asumsi klasik dilanjutkan dengan melakukan uji regresi berganda yaitu uji t untuk uji parsial dan uji F untuk uji silmultan.

\section{Hipotesis Penelitian}

Hipotesis dalam penelitian ini adalah:

H1: NPF berpengaruh negatif dan signifikan terhadap ROE

H2: FDR berpengaruh positif dan signifikan terhadap ROE

H3 : CAR berpengaruh positif dan signifikan terhadap ROE

H4 : NPF, FDR dan CAR secara simultan berpengaruh positif dan signifikan terhadap ROE.

\section{PEMBAHASAN}

\subsection{Pengertian Bank Syariah}

Bank syari'ah didefiniskan sebagai bank yang melaksanakan kegiatan usaha berdasarkan prinsip Syari'ah, yaitu aturan perjanjian berdasarkan hukum Islam antara bank dan pihak lain untuk penyimpanan dana dan atau pembiayaan kegiatan usaha, atau kegiatan lainnya yang dinyatakan sesuai dengan Syari'a $h^{6}$. Sedangkan Bank Syariah menurut UndangUndang No. 21 Tahun 2008 tentang perbankan syari'ah, bank syari'ah adalah bank yang menjalankan kegiatan usahanya berdasarkan prinsip syari'ah dan menurut jenisnya terdiri atas Bank Umum Syari'ah, Unit Usaha Syari'ah dan Bank Pengkreditan Rakyat Syari'ah (BPRS) ${ }^{7}$.

Dalam operasionalnya, bank syariah selain menghindari riba, bank syari'ah juga secara aktif turut berpartisipasi dalam mencapai sasaran dan tujuan dari ekonomi Islam yang berorientasi pada kesejahteraan sosial (falah) ${ }^{8}$. Praktek larangan riba, gharar dan maysir menjadi landasan dan filosofi dalam operasional bank syariah. Dalam Al-Qur'an Surat AlBaqarah ayat 278 Allah berfirman:

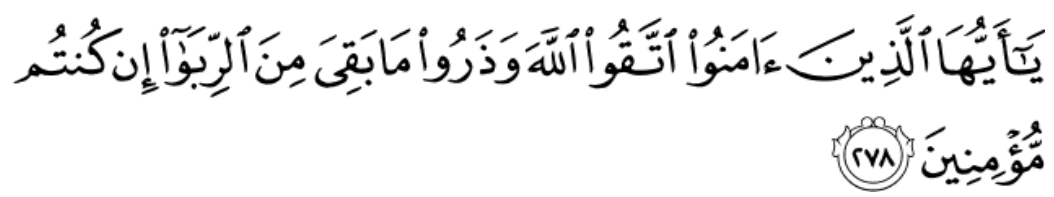

\footnotetext{
${ }^{6}$ Ascarya dan Diana Yumanita. 2005. Bank Syari'ah: Gambaran Umum. Jakarta: Pusat Pendidikan dan Studi Kebanksentralan (PPSK) Bank Indonesia. hlm 1

${ }^{7}$ Andri Soemitra. 2009. Bank dan Lembaga Keuangan Syariah. Jakarta : Kencana. hlm. 61-62

${ }^{8}$ Ascarya dan Diana Yumanita, Bank Syari'ah: Gambaran Umum. hlm 4
} 
Artinya: "Wahai orang-orang yang beriman, bertakwalah kepada Allah, dan tinggalkan sisa riba jika kamu adalah orang-orang yang beriman". (QS. Al-Baqarah : 278)

Dari ayat tersebut diatas, Allah memerintahkan kita untuk meninggalkan sisa riba. Sehingga sebagai orang yang beriman kita harus melaksanakan apa yang sudah diperintahkan kepada kita. Selain landasan agama yang bersumber dari Al-Qur'an dan hadist, praktek operasional bank syariah juga didasarkan pada UU No.10 Tahun 1998 tentang perubahan atas undang-undang No.7 Tahun 1992 dan UU No.23 Tahun 2003 tentang Bank Indonesia.

\subsection{Non Performing Financing (NPF) Bank Syariah}

Non Performing Financing (NPF) adalah rasio yang digunakan untuk mengukur kemampuan bank dalam meng-cover risiko kegagalan pengembalian pembiayaan oleh debitur. ${ }^{9}$ Non Performing Financing (NPF) merupakan salah satu indikator kesehatan kualitas asset bank dalam mengelola penyaluran pembiayaan. Penilaian kualitas aset merupakan penilaian terhadap kondisi aset Bank dan kecukupan manajemen risiko pembiayaan, Menurut Peraturan Bank Indonesia Nomor 6/10/ PBI/2004 tanggal 12 april 2004 tentang sistem penilaian Tingkat Kesehatan Bank Umum dan Bank Syariah, semakin tinggi nilai NPF (diatas $5 \%$ ), maka bank tersebut tidak sehat 10. Non Performing Financing (NPF) dapat dirumuskan sebagai berikut ${ }^{11}$ :

$$
\mathrm{NPF}=\frac{\text { Pembiayaan Bermasalah }}{\text { Total Pembiayaan }} \times 100 \%
$$

\subsection{Financing to Deposit Ratio (FDR) Bank Syariah}

Financing to Deposit Ratio (FDR) merupakan perbandingan antara pembiayaan yang diberikan oleh bank dengan dana pihak ketiga yang berhasil dihimpun oleh bank. Pembiayaan ini antara lain adalah ${ }^{12}$ :

a. Pembiayaan yang disalurkan kepada masyarakat dikurangi dengan pembiayaan sindikasi yang dibiayai bank lain;

\footnotetext{
${ }^{9}$ Nur Suhartatik, "Determinan Finacing To Deposit Ratio Perbankan Syari'ah Di Indonesia (20082012)," Jurnal Ilmu Manajemen 1, no. 4 (2015).Nur Suhartatik. 2015. Determinan Finacing To Deposit Ratio Perbankan Syari'ah di Indonesia (2008-2012).

${ }^{10}$ Ali Idrus, "Pengaruh Faktor Internal Dan Eksternal Terhadap Return On Equity ( ROE )," Misykat AlAnwar Kajian Islam Dan Masyarakat 29, no. 2 (2018): 79-98, https://doi.org/10.31904/ma.v29i2.2852.

${ }^{11}$ Maidalena, "Analisis Faktor Non Performance Financing (NPF) Pada Industri Perbankan Syari'ah." (UIN Sumatra Utara, 2014). Hal: 131

12 Idrus, “Pengaruh Faktor Internal Dan Eksternal Terhadap Return On Equity ( ROE ).”hal: 84
} 
b. Penanaman pada bank lain dalam bentuk pembiayaan yang diberikan dengan jangka waktu lebih dari 3 bulan;

c. Penanaman pada bank lain, dalam bentuk pembiayaan dalam rangka pembiayaan sindikasi.

Sedangkan dana pihak ketiga yang dihimpun oleh bank syariah antara lain adalah:

1. Deposito dan tabungan masyarakat;

2. Pinjaman bukan dari bank lain dengan jangka waktu lebih dari 3 bulan (di luar pinjaman subordinasi); a) deposito dan pinjaman dari bank lain dengan jangka waktu lebih dari 3 bulan; b) modal inti dan; c) modal pinjaman

Untuk menghitung FDR dapat dirumuskan sebagai berikut:

$$
\mathrm{FDR}=\frac{\text { Jumlah pembiayaan }}{\text { Total Dana Pihak Ketiga }} \times 100 \%
$$

Nilai FDR yang ditentukan oleh Bank Indonesia adalah pada kisaran 78\% hingga $100 \%$.

\subsection{Capital Adquacy Ratio (CAR) Bank Syariah}

Capital Adequacy Ratio (CAR) adalah rasio kecukupan modal yang fungsinya untuk menanggung risiko kerugian yang kemungkinan dihadapi oleh bank. Semakin tinggi CAR bank syariah menunjukkan semakin baik kemampuan bank tersebut untuk menanggung risiko dari setiap pembiayaan atau aktiva produktif yang berisiko. Capital Adquacy Ratio (CAR) merupakan kebutuhan modal minimum bank yang dihitung berdasarkan Aktiva Tertimbang Menurut Risiko (ATMR). Menurut Bank Indonesia, besarnya minumum Capital Adquacy Ratio (CAR) adalah sebesar 8\%. Nilai CAR dapat dihitung dengan menggunakan rumus ${ }^{13}$ :

$$
\mathrm{CAR}=\frac{\text { Modal }}{\text { ATMR }} \times 100 \%
$$

\subsection{Return On Equity (ROE) Bank Syariah}

Return on Equity (ROE) atau rasio laba setelah pajak terhadap modal sendiri. Rasio ini mengukur kemampuan perusahaan menghasilkan laba berdasarkan modal tertentu. Rasio ini merupakan ukuran profitabilitas dari sudut pandang pemegang saham. Rumus yang digunakan adalah: ${ }^{14}$

$$
\mathrm{ROE}=\frac{\text { Laba bersih }}{\text { Total } \text { ekuitas }} \mathrm{X} 100 \%
$$

13 Otoritas Jasa Keuangan (OJK), "Surat Edaran Otoritas Jasa Keuangan No.10/SEOJK.03/2014 Tentang Penilaian Tingkat Kesehatan Bank Umum Syariah Dan Unit Usaha Syari'ah,” (2014).

${ }^{14}$ ibid 
Rasio return on equity (ROE) adalah titik awal yang baik dalam analisis kondisi keuangan bank karena alasan berikut ${ }^{15}$ :

a) Apabila ROE relatif rendah dibandingkan dengan bank lain, ROE akan cenderung mengurangi akses bank untuk mendapatkan modal baru yang mungkin diperlukan untuk memperluas dan mempertahankan posisi kompetitif di pasar.

b) Prosentasi ROE dengan nilai rendah bisa membatasi perkembangan bank disebabkan peraturan mengharuskan aset (pada nilai maksimum) menjadi jumlah tertentu dari modal ekuitas.

c) ROE dapat digunakan untuk membantu untuk mengidentifikasi tren dalam kinerja bank.

\subsection{Paparan Hasil Penelitian}

Dengan menggunakan SPSS 25 dilakukan uji statistik deskriptif, uji asumsi klasik dan hasil pengolahan data dalam penelitian ini adalah sebagai berikut:

\section{1) Uji Statistik Deskriptif}

\begin{tabular}{|c|c|c|c|c|c|}
\hline \multicolumn{6}{|c|}{ Statistics } \\
\hline & & NPF & FDR & CAR & ROE \\
\hline \multirow[t]{2}{*}{$\mathrm{N}$} & Valid & 80 & 80 & 80 & 80 \\
\hline & Missing & 0 & 0 & 0 & 0 \\
\hline \multicolumn{2}{|c|}{ Mean } & 2.9344 & 77.9884 & 16.7876 & 6.8206 \\
\hline \multicolumn{2}{|c|}{ Median } & 2.9500 & 76.6350 & 15.6300 & 5.8750 \\
\hline \multicolumn{2}{|c|}{ Std. Deviation } & 1.17238 & 8.34440 & 4.65407 & 4.93347 \\
\hline \multicolumn{2}{|c|}{ Minimum } & 1.22 & 60.54 & 11.67 & .45 \\
\hline \multicolumn{2}{|c|}{ Maximum } & 4.99 & 95.47 & 29.67 & 25.61 \\
\hline
\end{tabular}

Sumber: Hasil pengolahan data SPSS 25

Dari hasil pengolahan data diatas menunjukaan bahwa NPF rata-rata sebesar 2.934 dengan standar deviasi 1.17. ini menunjukkan bahwa standar diveiasi NPF lebih kecil dari nilai rata-rata sehingga mengindikasikan hasil yang baik yang variabel NPF. Demikian juga untuk variabel FDR, CAR dan ROE.

\section{2) Uji Normalitas}

Menggunakan Smirnov Kolmogorov. Uji normalitas ini bertujuan untuk mengetahui apa nilai residual berdistrubusi normal atau tidak. Model regresi yang baik adalah yang residualnya

15 Idrus, “Pengaruh Faktor Internal Dan Eksternal Terhadap Return On Equity ( ROE ).” Hal: 82 
berdistrubusi normal. Berdasarkan hasil uji normalitas Smirnov Klomogorov diketahui nilai signifikansi $0.200>0.05$ maka dapat disimpulkan bahwa nilai residual berdistrubusi normal.

\section{3) Uji Linieritas}

Uji linieritas dilakukan untuk mengetahui linier atau tidaknya hubungan antara variabel terikat dengan variabel bebas. Berdasakan hasil pengujian diketahui bahwa nilai Sig Deviation From Liniarity $<0.05$ maka terdapat hubungan yang linier antara variabel bebas dan variabel terikatnya.

\section{4) Uji Heteroskedastisitas}

Uji asumsi klasik yang digunakan untuk menguji apakah pada model regresi terjadi ketidaksamaan variance dari nilai residual satu pengamatan ke pengamatan yang lain pada model regresi. Model regresi yang baik adalah yang tidak ada gejala heteroskedastisitas. Uji heteroskedastisitas pada penelitian ini dilakukan dengan menggunakan uji geljser.

\begin{tabular}{|c|c|c|c|c|c|c|}
\hline \multicolumn{7}{|c|}{ Coefficients $^{a}$} \\
\hline & & \multicolumn{2}{|c|}{$\begin{array}{c}\text { Unstandardized } \\
\text { Coefficients }\end{array}$} & \multirow{2}{*}{$\begin{array}{c}\begin{array}{c}\text { Standardized } \\
\text { Coefficients }\end{array} \\
\text { Beta }\end{array}$} & \multirow[b]{2}{*}{$\mathrm{t}$} & \multirow[b]{2}{*}{ Sig. } \\
\hline \multicolumn{2}{|c|}{ Model } & B & Std. Error & & & \\
\hline \multirow[t]{4}{*}{1} & (Constant) & 3.536 & 1.858 & & 1.903 & .075 \\
\hline & NPF & -.032 & .352 & -.022 & -.091 & .929 \\
\hline & FDR & .000 & .000 & -.314 & -1.269 & .223 \\
\hline & CAR & -.071 & .098 & -.178 & -.725 & .479 \\
\hline
\end{tabular}

a. Dependent Variable: ABS_RES

Dari hasil pengujian tersebut menunjukkan bahwa :

- Variabel NPF mempunyai nilai signifikansi $0.929>0.05$ sehingga disimpukan tidak terjadi heteroskedastisitas

- Variabel FDR mempunyai nilai signifikansi $0.223>0.05$ sehingga disimpulkan tidak terjadi heteroskedstisitas

- Variabel CAR mempunyai nilai signifikansi 0.479 sehingga disimpulkam tidak terjadi heteroskedastisitas

\section{5) Uji Multikolinieritas}

Uji ini digunakan untuk mengetahui apakah terjadi interkorelasi (hubungan yang kuat) antar variabel independent. Model regresi yang baik adalah yang tidak terjadi gejala multikolinieritas. Uji multikolinieritas dilakukan dengan melihat VIF. Jika nilai Tolerance > 
0.10 maka tidak terjadi multikolinieritas. dari hasil analisisi data diperoleh nilai VIF NPF adalah 1.096 > 0.10; nilai VIF FDR adalah 1.099 > 0.10; nilai VIF CAR adalah sebesar $1.073>$ 0.10. seluruh nilai VIF pada variabel independen dalam penelitian ini lebih besar dari 0.10 sehingga disimpulkan bahwa tidak terjadi gejala multikolinieritas.

\section{6) Uji Autokorelasi}

Uji autokorelasi bertujuan untuk menguji apakah dalam model regresi linier ada korelasi antara kesalahan pengganggu pada periode $\mathrm{T}$ dengan kesalahan pengganggu pada periode sebelumnya (T-1). Uji ini diperlukan ketika data penelitian adalah time series. Uji autokorelasi dengan menggunakan Durbin Watson.

Jika DU $<$ D $<4$-D maka tidak terjadi autokorelasi.

\begin{tabular}{|l|r|r|r|r|r|}
\hline \multicolumn{7}{|c|}{ Model Summary $^{\text {Model }}$} & $\mathrm{R}$ & R Square & $\begin{array}{c}\text { Adjusted R } \\
\text { Square }\end{array}$ & $\begin{array}{c}\text { Std. Error of } \\
\text { the Estimate }\end{array}$ & $\begin{array}{c}\text { Durbin- } \\
\text { Watson }\end{array}$ \\
\hline 1 & $.798^{\mathrm{a}}$ & .637 & .569 & 3.077 & 1.942 \\
\hline \multicolumn{7}{|l}{ a. Predictors: (Constant), CAR, NPF, FDR } \\
\hline
\end{tabular}

Sumber: Hasil pengolahan data SPSS 25

\begin{tabular}{|c|c|c|c|c|c|}
\hline $\mathrm{N}$ & $\mathrm{D}$ & $\mathrm{DL}$ & $\mathrm{DU}$ & \multicolumn{1}{|c|}{ 4-DL } & $4-\mathrm{DU}$ \\
\hline 80 & 1.942 & 0.53 & 1.74 & 3.47 & 2.26 \\
\hline
\end{tabular}

Dari hasil analisis data diatas diketahui bahwa nilai DU $<$ D $<4$-D adalah $1.74<1.942$ $<2.26$ maka disimpulkan tidak terjadi autokorelasi.

7) Uji Hipotesis

Uji Parsial atau uji t

\begin{tabular}{|c|c|c|c|c|c|c|}
\hline \multicolumn{7}{|c|}{ Coefficients $^{a}$} \\
\hline & & \multicolumn{2}{|c|}{$\begin{array}{c}\text { Unstandardized } \\
\text { Coefficients }\end{array}$} & $\begin{array}{c}\text { Standardized } \\
\text { Coefficients }\end{array}$ & \multirow[b]{2}{*}{$\mathrm{t}$} & \multirow[b]{2}{*}{ Sig. } \\
\hline \multicolumn{2}{|c|}{ Model } & $\mathrm{B}$ & Std. Error & Beta & & \\
\hline \multirow[t]{4}{*}{1} & (Constant) & 12.475 & 3.049 & & 4.091 & .001 \\
\hline & NPF & -2.950 & .577 & -.806 & -5.111 & .000 \\
\hline & FDR & -.001 & .000 & -.383 & -2.429 & .027 \\
\hline & CAR & .154 & .161 & .150 & .959 & .352 \\
\hline
\end{tabular}

a. Dependent Variable: ROE

Dasar pengambilan keputusan dalam uji t adalah sebagai berikut: 
$>$ Jika Sig $<0.05$ atau $\mathrm{T}_{\text {hitung }}>\mathrm{T}_{\text {tabel }}$ maka terdapat pengaruh signifikan antara variabel $\mathrm{X}$ thd $\mathrm{Y}$

$>$ Jika Sig $>0.05$ atau $\mathrm{T}_{\text {hitung }}<\mathrm{T}_{\text {tabel }}$ maka tidak terdapat pengaruh signifikan antara variabel $\mathrm{X}$ thd $\mathrm{Y}$

$>\mathrm{T}_{\text {tabel }}=\mathrm{t}(\alpha / 2 ; \mathrm{n}-\mathrm{k}-1)$ dimana $=$ jumlah sampel, $\mathrm{K}=$ jumlah variabel $\mathrm{X}$

Ttabel $=0.025 ; 76$. Sehingga $\mathrm{T}$ tabel $=1.99$

$>$ Ftabel $=\mathrm{F}(\mathrm{k}: \mathrm{n}-\mathrm{k}) . \mathrm{F}$ tabel $=2.72$

\section{I.7 Pengaruh NPF terhadap ROE}

H1: NPF berpengaruh negatif dan signifikan terhadap ROE

Berdasarkan hasil uji t dalam penelitian ini didapatkan nilai t sebesar -5.11 dengan signikansi 0.000 sehingga $\mathrm{T}_{\text {hitung }}>\mathrm{T}_{\text {tabel }}(-5.11>1.99)$ dan signifikansi $0.000<0.05$ sehingga diputuskan untuk menerima hipotesis pertama yaitu bahwa NPF berpengaruh negatif dan signikan. Hal ini sesuai dengan teori bahwa hubungan antara Non Perfomance Financing (NPF) dengan Return On Asset (ROE) adalah berbanding terbalik sehingga semakin kecil nilai NPF maka ROE yang diperoleh oleh Bank Syariah akan semakin besar dan sebaliknya. Hal ini terjadi karena semakin bagus kinerja Bank Syariah dalam mengelola pembiayaan macet maka akan semakin kecil nilai NPF. Jika NPF semakin kecil menunjukkan bank syariah mampu melakukan pengendalian internal pembiayaan ${ }^{16}$. Sehingga maka laba yang diperoleh Bank Syariah yang diproksikan dengan ROE akan semakin besar.

\section{I.8 Pengaruh FDR terhadap ROE}

H2: FDR berpengaruh positif dan signifikan terhadap ROE

Berdasarkan hasil uji t dalam penelitian ini didapatkan nilai t sebesar -2.249 dengan signikansi 0.000 sehingga $\mathrm{T}_{\text {hitung }}>\mathrm{T}_{\text {tabel }}(-2.249>1.99)$ dan signifikansi $0.27>0.05$ sehingga diputuskan untuk menolak hipotesis kedua. Dalam penelitian ini menunjukkan bahwa FDR bepengaruh negatif dan tidak signifikan terhadap ROE. Artinya semakin tinggi nilai FDR akan semakin menurunkan nilai ROE namun tidak secara signifikan. Hal ini dikarenakan bahwa FDR tidak berhubungan secara langsung terhadap ROE, namun FDR berhubungan langsung dengan ROA. Dimana ROA adalah rasio laba sebelum pajak terhadap rata-rata aktiva dalam periode yang sama. Sementara itu FDR merupakan rasio yang menunjukkan besarnya jumlah pembiayaan terhadap dana yang dihimpun dari pihak ketiga. Sehingga FDR lebih berhubungan secara langsung terhadap laba bank syariah bukan terhadap ekuitas bank syariah.

${ }^{16}$ Saiful Muslim, "Analisis Pengendalian Internal Pembiayaan Murabahah Di BMT Al-Hijrah Kan Jabung Syariah Jatim,” An-Nisbah: Jurnal Perbankan Syariah 1, no. 1 (2020): 41-56. 


\section{I.9 Pengaruh CAR terhadap ROE}

H3 : CAR berpengaruh positif dan signifikan terhadap ROE

Berdasarkan hasil uji t dalam penelitian ini didapatkan nilai t sebesar 0.959 dengan signikansi 0.352 sehingga $\mathrm{T}_{\text {hitung }}<\mathrm{T}_{\text {tabel }}(0.959>1.99)$ dan signifikansi $0.352>0.05$ sehingga diputuskan untuk menolak hipotesis. Dalam penelitian ini menunjukkan bahwa CAR berpengaruh positif tidak signifikan terhadap ROE. Artinya bahwa semakin tinggi nilai CAR maka akan semakin besar pula nilai ROE bank syariah, namun hal ini tidak secara signifikan berpengaruh. Hal ini karena semakin tinggi CAR maka menunjukkan bahwa bank syariah tersebut mempunyai likuiditas yang gemuk sehingga kurang efisien didalam melakukan pembiayaan. CAR yang ditetapkan oleh Bank Indonesia adalah minimal sebesar 8\%. Jika bank syariah mempunyai nilai CAR yang telalu kecil menunjukkan bahwa bank syariah bisa saja mengalami kesulitas likuiditas, namun jika bank syariah mempunyai nilai CAR yang terlalu gemuk menunjukkan bank syariah kurang efisien dalam melakukan pembiayaan. Dengan demikian CAR berpengaruh positif namun tidak signikan terhadap ROE.

\section{I.10 Pengaruh NPF, FDR, dan CAR terhadap ROE}

H4 : NPF, FDR dan CAR secara simultan berpengaruh positif dan signifikan terhadap ROE.

\begin{tabular}{|c|c|c|c|c|c|c|}
\hline \multicolumn{7}{|c|}{ ANOVA $^{a}$} \\
\hline \multicolumn{2}{|c|}{ Model } & $\begin{array}{c}\text { Sum of } \\
\text { Squares }\end{array}$ & Df & Mean Square & $\mathrm{F}$ & Sig. \\
\hline \multirow[t]{3}{*}{1} & Regression & 266.058 & 3 & 88.686 & 9.369 & $.001^{\mathrm{b}}$ \\
\hline & Residual & 151.448 & 16 & 9.465 & & \\
\hline & Total & 417.506 & 19 & & & \\
\hline \multicolumn{7}{|c|}{ a. Dependent Variable: ROE } \\
\hline \multicolumn{7}{|c|}{ b. Predictors: (Constant), CAR, NPF, FDR } \\
\hline
\end{tabular}

Sumber: Hasil pengolahan data SPSS 25

Berdasarkan hasil uji F dalam penelitian ini didapatkan nilai F sebesar 9.369 dengan signikansi 0.001 sehingga $\mathrm{F}_{\text {hitung }}>\mathrm{T}_{\text {tabel }}(9.359>2.72)$ dan signifikansi $0.001<0.05$ sehingga diputuskan untuk menerima hipotesis yaitu bahwa secara simultan NPF, FDR dan CAR berpengaruh positif dan signifikan terhadap ROE. Hal ini menunjukkan bahwa jika bank syariah bisa mengelola pembiayaan macet, mengatur jumlah pembiayaan dari dana pihak ketiga dan mampu menjaga nilai kecukupan modal maka ekuitas bank syariah bisa meningkat. Hal ini dikarenakan bank syariah telah mampu melaksanakan kinerjanya secara ideal sesuai dengan yang ditetapkan oleh Bank Indonesia. 


\section{SIMPULAN DAN SARAN}

\section{Simpulan}

Dari uraian diatas maka dapat diambil kesimpulan:

1) Berdasarkan hasil uji $t$ dalam penelitian ini didapatkan nilai $t$ sebesar -5.11 dengan signikansi 0.000 sehingga $T_{\text {hitung }}>T_{\text {tabel }}(-5.11>1.99)$ dan signifikansi $0.000<0.05$. Sehingga NPF berpengaruh negatif dan signikan. semakin bagus kinerja Bank Syariah dalam mengelola pembiayaan macet maka akan semakin kecil nilai NPF. Jika NPF semakin kecil maka laba yang diperoleh Bank Syariah yang diproksikan dengan ROE akan semakin besar.

2) Berdasarkan hasil uji $t$ dalam penelitian ini didapatkan nilai $t$ sebesar -2.249 dengan signikansi 0.000 sehingga $\mathrm{T}_{\text {hitung }}>\mathrm{T}_{\text {tabel }}(-2.249>1.99)$ dan signifikansi $0.27>0.05$ sehingga FDR berpengaruh negatif dan tidak signifikan terhadap ROE.

3) Berdasarkan hasil uji $t$ dalam penelitian ini didapatkan nilai $t$ sebesar 0.959 dengan signikansi 0.352 sehingga $T_{\text {hitung }}<T_{\text {tabel }}(0.959>1.99)$ dan signifikansi $0.352>0.05$ sehingga CAR berpengaruh positif dan tidak signifikan terhadap ROE. Artinya bahwa semakin tinggi nilai CAR maka akan semakin besar pula nilai ROE bank syariah, namun hal ini tidak secara signifikan berpengaruh.

4) Berdasarkan hasil uji $\mathrm{F}$ dalam penelitian ini didapatkan nilai $\mathrm{F}$ sebesar 9.369 dengan signikansi 0.001 sehingga $F_{\text {hitung }}>T_{\text {tabel }}(9.359>2.72)$ dan signifikansi $0.001<0.05$ sehingga secara simultan NPF, FDR dan CAR berpengaruh positif dan signifikan terhadap ROE.

\section{Saran}

Saran dari penelitian ini adalah dalam penelitian profitabiltas bank syariah diproksikan dengan menggunakan Return On Equity (ROE). Sehingga untuk penelitian selanjutnya bisa ditambahkan profiltasbilitas bisa diukur juga dengan Return on Asset (ROA) dan Net Profit Margin (NPM) sehingga kita bisa melihat bagaimana pengaruh NPF, FDR dan CAR terhadap profitabilitas bank syariah dengan menggunakan variabel yang lain. 


\section{DAFTAR PUSTAKA}

Ascarya dan Diana Yumanita. 2005. Bank Syari'ah: Gambaran Umum. Jakarta: Pusat Pendidikan dan Studi Kebanksentralan (PPSK) Bank Indonesia.

(OJK), Otoritas Jasa Keuangan. Surat Edaran Otoritas Jasa Keuangan No.10/SEOJK.03/2014 Tentang Penilaian Tingkat Kesehatan Bank Umum Syariah dan Unit Usaha Syari'ah, (2014).

Almunawwaroh, Medina. "Pengaruh CAR, NPF Dan FDR Terhadap Profitabilitas Bank Syariah Di Indonesia." Amwaluna: Jurnal Ekonomi Dan Keuangan Syariah 2, no. 1 (2018): 1-18. https://doi.org/https://doi.org/10.29313/amwaluna.v2i1.3156.

Hayati, Safaah Restuning. "Peran Perbankan Syariah Terhadap Pertumbuhan Ekonomi Indonesia." Indo-Islamika 24, no. 1 (2014): 47-55.

Idrus, Ali. "Pengaruh Faktor Internal Dan Eksternal Terhadap Return On Equity ( ROE )." Misykat Al-Anwar Kajian Islam Dan Masyarakat 29, no. 2 (2018): 79-98. https://doi.org/10.31904/ma.v29i2.2852.

Maidalena. "Analisis Faktor Non Performance Financing (NPF) Pada Industri Perbankan Syari'ah.” UIN Sumatra Utara, 2014.

Munir, Misbahul. "Analisis Pengaruh CAR, NPF, FDR Dan Inflasi Terhadap Profitabilitas Perbankan Syariah Di Indonesia." Ihtifaz: Journal of Islamics, Finance, and Banking 1, no. 2 (2018).

Muslim, Saiful. "Analisis Pengendalian Internal Pembiayaan Murabahah Di BMT Al-Hijrah Kan Jabung Syariah Jatim." An-Nisbah: Jurnal Perbankan Syariah 1, no. 1 (2020): 41-56.

Suhartatik, Nur. "Determinan Finacing To Deposit Ratio Perbankan Syari'ah Di Indonesia (2008-2012)." Jurnal Ilmu Manajemen 1, no. 4 (2015). 